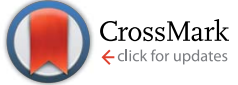

Cite this: RSC Adv., 2017, 7, 9258

Received 5th November 2016 Accepted 26th January 2017

DOI: 10.1039/c6ra26342a

rsc.li/rsc-advances

\section{Optimization of the window layer in large area silicon heterojunction solar cells}

\author{
Yue Zhang, ${ }^{a}$ Cao Yu, ${ }^{b}$ Miao Yang, ${ }^{b}$ Yongcai He, ${ }^{a}$ Linrui Zhang, ${ }^{a}$ Jinyan Zhang, ${ }^{b}$ \\ Xixiang Xu, ${ }^{b}$ Yongzhe Zhang, ${ }^{* a}$ Xuemei Song ${ }^{a}$ and Hui Yan*a
}

Silicon heterojunction solar cells have shown great advantage due to their large open-circuit voltage which induces a high energy conversion efficiency. However, the short-circuit current density is limited by the high light absorption of an n-type amorphous silicon window layer in the short-wavelength range. Here an amorphous silicon oxide film was introduced to replace the window layer. The increasing oxygen content in amorphous silicon oxide layers leads to the enlarged optical band gap and the enhanced short-wavelength transmittance. As a result, the short-circuit current density increases obviously which comes from the high transmittance of amorphous silicon oxide films due to the wider band gap. Furthermore, the highly phosphorous-doped amorphous silicon layer was introduced to improve the contact between transparent conductive oxide layer and n-type amorphous silicon oxide layer. The carrier transport property is enhanced and thus the fill factor increases significantly. Finally, a silicon heterojunction solar cell with an area of $238.95 \mathrm{~cm}^{2}$ was prepared, yielding a total-area efficiency up to $21.1 \%$. Overall, the results indicate that amorphous silicon oxide films can be applied to silicon heterojunction solar cells as a window layer, which provides a new route to obtain higher energy conversion efficiency.

\section{Introduction}

Silicon heterojunction ( $\mathrm{SHJ}$ ) solar cells are fabricated through depositing thin hydrogenated amorphous silicon (a-Si:H) layers on crystalline silicon substrates. ${ }^{1}$ Due to the outstanding passivation effect of the intrinsic a-Si:H films, ${ }^{2,3} \mathrm{SHJ}$ solar cells show high open-circuit voltage $\left(V_{\text {OC }}\right)$ exceeding $750 \mathrm{mV}^{3}$ which leads to high energy conversion efficiency. ${ }^{4}$ Upon the intrinsic a$\mathrm{Si}: \mathrm{H}$ films, doped (n-type or p-type) a-Si:H film is generally deposited to form a junction, which could separate the photogenerated carriers effectively. ${ }^{5}$ However, both the intrinsic and doped a-Si:H films contain lots of defects due to the presence of dangling bonds. ${ }^{6}$ In the respect of light absorption, it shows a high absorption in the short wavelength region (below 730 $\mathrm{nm}$ ) due to the high absorption coefficient which comes from the quasi-direct band gap property of a-Si:H.,8 Although the high absorption could lead to more photo-generated carriers, these carriers could not be pumped out due to the present of large density of defects. ${ }^{9}$ Z. C. Holman et al. pointed out that $70 \%$ carriers generated in intrinsic a-Si:H layers of heterojunctions recombined, and light absorbed in the doped a-Si:H layer had almost no contribution to short-circuit current

${ }^{a}$ The College of Materials Science and Engineering, Beijing University of Technology, Beijing 100124, PR China. E-mail: yzzhang@bjut.edu.cn; hyan@bjut.edu.cn; Tel: +86-10-6739-2445

${ }^{b}$ Hanergy Thin Film Power, $R \&$ D Center, Chengdu, Sichuan 610200, PR China density $\left(J_{\mathrm{SC}}\right){ }^{9}$ So decreasing the parasitic absorption of a-Si:H layers is a key point to improve $J_{\mathrm{SC}}$. It has been demonstrated that decreasing the thickness of a-Si:H films is a useful method to improve $J_{\mathrm{SC}}$ by decreasing absorption in short-wavelength region. However, the fill factor (FF) and $V_{\mathrm{OC}}$ of $\mathrm{SHJ}$ solar cells decreased significantly because of the degrading of junction, ${ }^{\mathbf{1 0 - 1 2}}$ the gain in $J_{\mathrm{SC}}$ was offset by losses in $\mathrm{FF}$ and $V_{\mathrm{OC}}$.

Compared with a-Si:H films, hydrogenated amorphous

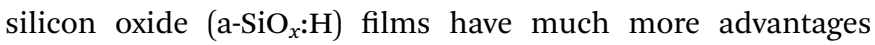
including wider band-gap and lower optical absorption. ${ }^{13}$ The absorption loss in short-wavelength region could be significantly reduced by adopting $\mathrm{a}-\mathrm{SiO}_{x}: \mathrm{H}$ films and this strategy has worked in amorphous silicon solar cells. ${ }^{\mathbf{1 4 , 1 5}} \mathrm{R}$. Biron et al. observed an enhancement of $0.6 \mathrm{~mA} \mathrm{~cm}{ }^{-2}$ in $J_{\mathrm{SC}}$ in the shortwavelength region due to the enlargement of optical band gap of silicon oxide based emitter, ${ }^{\mathbf{1 6}}$ and other studies have obtained similar results. ${ }^{17,18}$ Here phosphorus-doped $\mathrm{a}_{-} \mathrm{SiO}_{x}: \mathrm{H}$ film was introduced to replace the n-type a-Si:H window layer. For the passivation layer, intrinsic a-Si:H film was left to keep an excellent passivation effect. ${ }^{19}$ The optical properties of n-type a$\mathrm{SiO}_{x}: \mathrm{H}$ films and the effect of n-type a-SiO ${ }_{x}: \mathrm{H}$ films on $\mathrm{SHJ}$ solar cell performance were investigated in details. By adjusting the $\mathrm{CO}_{2} / \mathrm{SiH}_{4}$ flow ratio, the optimized oxygen content in $\mathrm{a}-\mathrm{SiO}_{x}: \mathrm{H}$ films was obtained. Furthermore, highly phosphorous-doped a$\mathrm{Si}: \mathrm{H}$ films was introduced to improve the contact between transparent conducting oxide (TCO) and n-type a-SiO $\mathrm{S}_{x}: \mathrm{H}$ layers, which improved the FF obviously. Finally, SHJ solar cell with 
large area of $238.95 \mathrm{~cm}^{2}$ was achieved, yielding a high efficiency of $21.1 \%$. All these results obtained could be much useful to the industrial production of $\mathrm{SHJ}$ solar cell.

\section{Experimental}

The a-Si/c-Si heterojunction solar cells were fabricated on commercial solar grade Czochralski silicon wafers (n type, 2-5 $\Omega \mathrm{cm}, 200 \mu \mathrm{m}$ thick, (100) oriented, $238.95 \mathrm{~cm}^{2}$ wafer size). Surface texture was formed wet-chemically by alkaline process (aqueous solution of potassium hydroxide $(1.5 \% \mathrm{wt})$ ), then cleaned by RCA process before transferred to deposition chamber. Very high frequency plasma enhanced chemical vapor deposition (VHF-PECVD, $40 \mathrm{MHz}$ ) reactor was used to prepare a$\mathrm{SiO}_{x}: \mathrm{H}$ and a-Si:H films, the power density is $15 \mathrm{~mW} \mathrm{~cm} \mathrm{~cm}^{-2}$ and the deposition pressure is $30 \mathrm{~Pa}$. The TCO layers (indium tin oxide, $10 \%$ wt $\mathrm{SnO}_{2}$-doped $\mathrm{In}_{2} \mathrm{O}_{3}$ ceramic target) and the silver back electrode were prepared by magnetron sputtering. Cells were finished with forming front electrodes by screen printing of silver paste. The structure of the a-Si/c-Si heterojunction solar cells is shown in Fig. 1.

The current density-voltage $(J-V)$ characteristics were obtained under standard test condition (STC, $25{ }^{\circ} \mathrm{C}, \mathrm{AM} 1.5 \mathrm{G}, 100$ $\mathrm{mW} \mathrm{cm}^{-2}$ ). External quantum efficiency (EQE) was used to evaluate the spectral response. Transmittance and reflectance were measured by PerkinElmer Lambda 950 spectrophotometer. Besides, $\mathrm{a}_{-} \mathrm{SiO}_{x}: \mathrm{H}$ and a-Si:H films were also investigated by Semilab PT-5 spectroscopic ellipsometry at room temperature using the Tauc-Lorentz method combined with the Bruggeman effective medium approximation (BEMA) model. Fourier transform infrared (FTIR) spectroscopy was used to verify the presence of oxygen for an approximately $100 \mathrm{~nm}$ thick layer. The one-sun (AM 1.5) photo-conductivity of different window $\mathrm{n}^{+}$layers was measured by coplanar electrodes method using Keithley 2410, and the voltage applied between the two electrodes is $5 \mathrm{~V}$. The length of the electrode is $16 \mathrm{~mm}$ and the spacing is $0.3 \mathrm{~mm}$.

\section{Results and discussion}

\subsection{Optical properties of $\mathbf{n}$ type $\mathbf{a}-\mathrm{SiO}_{x}: \mathrm{H}$}

Fig. 2(a) presents the optical transmittance $(T)$ and reflectance $(R)$ spectra of n-type $\mathrm{a}_{-} \mathrm{SiO}_{x}: \mathrm{H}$ films with the same thickness of

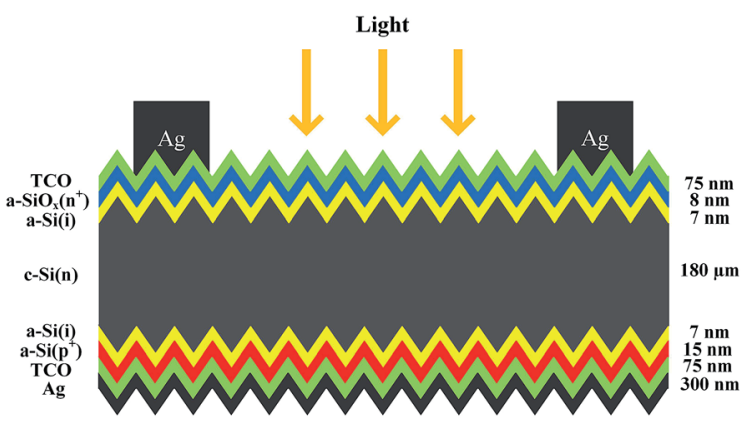

Fig. 1 The structure of the a-Si/c-Si heterojunction solar cells.
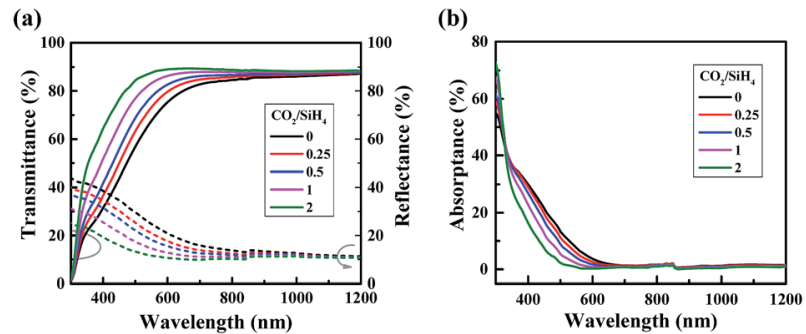

Fig. 2 Transmittance, reflectance (a) and absorptance (b) spectra of $n$ type a- $\mathrm{SiO}_{x}: \mathrm{H}$ films with various $\mathrm{CO}_{2} / \mathrm{SiH}_{4}$ flow ratios.

$8 \mathrm{~nm}$ deposited at various $\mathrm{CO}_{2} / \mathrm{SiH}_{4}$ flow ratios. It clearly shows that the transmittance of $\mathrm{a}-\mathrm{SiO}_{x}: \mathrm{H}$ films increases with the increasing of $\mathrm{CO}_{2} / \mathrm{SiH}_{4}$ flow ratio in the wavelength from 300 to $1200 \mathrm{~nm}$, especially in the region from 300 to $700 \mathrm{~nm}$. The calculated absorptance $(1-T-R)$ result is shown in Fig. 2(b), where an obvious drop in the short-wavelength region is present with adjusting the $\mathrm{CO}_{2} / \mathrm{SiH}_{4}$ flow ratio. Fig. 3 represents the refractive indices $(n)$ and extinction coefficients $(k)$ of n-type a$\mathrm{SiO}_{x}: \mathrm{H}$ films for an increasing $\mathrm{CO}_{2} / \mathrm{SiH}_{4}$ input flow ratio, derived from fitting spectroscopic ellipsometry data. It clearly shows that the refractive index decreases with the increase of $\mathrm{CO}_{2} / \mathrm{SiH}_{4}$ input flow ratio. This is the reason of the observed decrease of reflectance. It could be found that the extinction coefficient gradually decreases with the increase of $\mathrm{CO}_{2} / \mathrm{SiH}_{4}$ input flow ratio in the wavelength region from $300 \mathrm{~nm}$ to about $700 \mathrm{~nm}$. As is known, extinction coefficient and absorption coefficient are positively correlated. Therefore, in the wavelength region from $300 \mathrm{~nm}$ to about $700 \mathrm{~nm}$, the absorptance of a-SiO ${ }_{x}: \mathrm{H}$ films gradually decreases with the increase of $\mathrm{CO}_{2} / \mathrm{SiH}_{4}$ input flow ratio. In the wavelength region from $700 \mathrm{~nm}$ to $1200 \mathrm{~nm}$, extinction coefficients are zero, indicating that $\mathrm{a}-\mathrm{SiO}_{x}: \mathrm{H}$ films have no absorptance in this wavelength region. As a result of the differences in reflectance and absorptance, the transmittance of a-SiO $x: \mathrm{H}$ films increases with the increasing of $\mathrm{CO}_{2} / \mathrm{SiH}_{4}$ flow ratio in the wavelength from 300 to $1200 \mathrm{~nm}$. Particularly in the wavelength region from 300 to $700 \mathrm{~nm}$, due to the significant decrease of film absorptance, the increase of transmittance is more significant.

Fig. 4(a) shows the FTIR spectra of $\mathrm{a}-\mathrm{SiO}_{x}: \mathrm{H}$ layers for various $\mathrm{CO}_{2} / \mathrm{SiH}_{4}$ input flow ratios. The absorption peak between

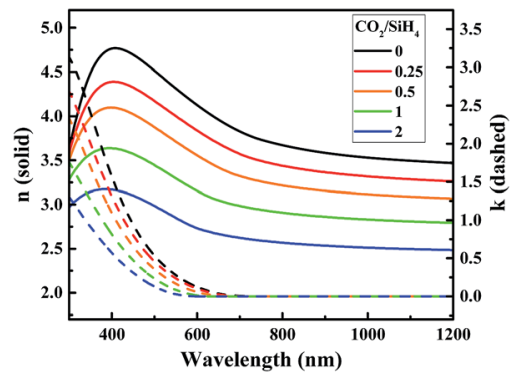

Fig. 3 Refractive indices $(n)$ and extinction coefficients ( $k$ ) of $n$-type a$\mathrm{SiO}_{x}: \mathrm{H}$ films with various $\mathrm{CO}_{2} / \mathrm{SiH}_{4}$ flow ratios derived from fitting spectroscopic ellipsometry data. 
(a)


Fig. 4 FTIR spectra of a-SiO : $\mathrm{H}$ layers for various $\mathrm{CO}_{2} / \mathrm{SiH}_{4}$ input flow ratios (a). Oxygen contents calculated from FTIR results (b).

$940 \mathrm{~cm}^{-1}$ and $1200 \mathrm{~cm}^{-1}$ represents the $\mathrm{Si}-\mathrm{O}-\mathrm{Si}$ stretching absorption band. ${ }^{20-22}$ It can be seen that the Si-O-Si stretching absorption gradually increases with the increase of $\mathrm{CO}_{2} / \mathrm{SiH}_{4}$ flow ratio. The oxygen concentration $\left(C_{\mathrm{O}}\right.$, units of at\%) in the a$\mathrm{SiO}_{x}: \mathrm{H}$ films is estimated from the $\mathrm{Si}-\mathrm{O}-\mathrm{Si}$ stretching absorption band following G. Lucovsky et $a .^{20}$ As is displayed in Fig. 4(b), the oxygen content gradually increases with the increase of $\mathrm{CO}_{2} / \mathrm{SiH}_{4}$ flow ratio. Because of higher bond energy of $\mathrm{Si}-\mathrm{O}$ bonds, ${ }^{23-25}$ the optical band gap $\left(E_{\text {opt }}\right)$ increases from $1.71 \mathrm{eV}$ to $2.08 \mathrm{eV}$, which is shown in Fig. 5. The relationship between $E_{\text {opt }}$ and absorption coefficient of a-SiO $\mathrm{S}_{x}: \mathrm{H}$ layers is displayed in eqn (1), ${ }^{24,25}$ where $B$ is a constant, $\hbar \omega$ is the energy of photon. According to eqn (1), absorption coefficient of a$\mathrm{SiO}_{x}: \mathrm{H}$ layers decreases with the widening of $E_{\text {opt }}$. So, the incorporation of oxygen in these films is the origination of the decreasing absorption in short wavelength region, ${ }^{\mathbf{1 9} 23}$ this verifies the result of $k$ presented in Fig. 3.

$$
\alpha(\omega) \hbar \omega=B\left(\hbar \omega-E_{\mathrm{g}}\right)^{2}
$$



Fig. 6 shows the illuminated $J-V$ results of solar cells featuring n-type a-SiO $x: \mathrm{H}$ window layers of various $\mathrm{CO}_{2} / \mathrm{SiH}_{4}$ flow ratios. As expected, $J_{\mathrm{SC}}$ shows a trend of increase. As is shown in Fig. 7, the enhancement of $J_{\mathrm{SC}}$ mainly originates from the improvement of spectral response in the short-wavelength region. This indicates that the high transmittance of $\mathrm{a}-\mathrm{SiO}_{x}: \mathrm{H}$ layers in shortwavelength region indeed contributes to the $J_{\mathrm{SC}}$.

As for $V_{\mathrm{OC}}$, a slight drop can be seen with the increase of $\mathrm{CO}_{2} /$ $\mathrm{SiH}_{4}$ flow ratio. In this experiment, as the p side of the cell does



Fig. 5 Optical band gap as a function of $\mathrm{CO}_{2} / \mathrm{SiH}_{4}$ flow ratio.

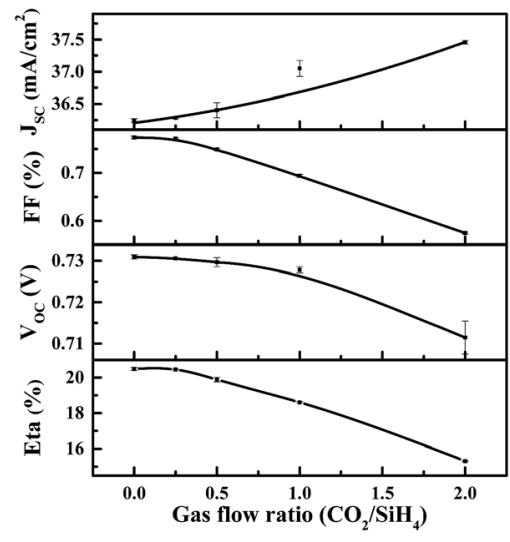

Fig. 6 Illuminated $\mathrm{J}-\mathrm{V}$ results of $\mathrm{SHJ}$ solar cells for various $\mathrm{CO}_{2} / \mathrm{SiH}_{4}$ input flow ratios.

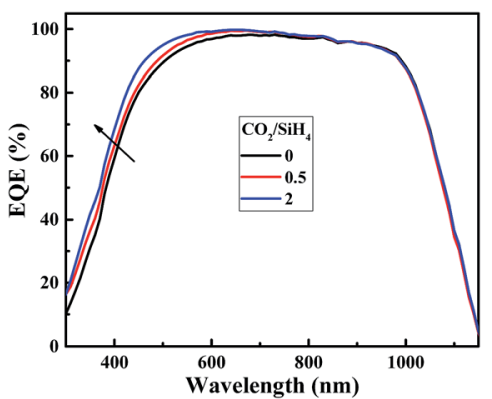

Fig. 7 EQE spectra of $\mathrm{SHJ}$ solar cells for various $\mathrm{CO}_{2} / \mathrm{SiH}_{4}$ input flow ratios.

not change, and $\mathrm{n}$ layers appear to have little detrimental effect on a-Si/c-Si chemical passivation quality. ${ }^{26}$ That means it is due to a loss in field effect passivation that the $V_{\text {OC }}$ goes down. It has been confirmed that fourfold coordinated phosphorus atoms become more unlikely with increasing oxygen content in a$\mathrm{SiO}_{x}: \mathrm{H}$ films, ${ }^{27}$ and the fourfold coordination of phosphorus atoms is crucial for an effective doping. ${ }^{28}$ This indicates that the doping efficiency of phosphorous in $\mathrm{a}^{-\mathrm{SiO}_{x}}: \mathrm{H}$ film decreases with rising oxygen content, and Fermi level moves towards the direction of middle of band gap. ${ }^{28}$ As a result, the built-in voltage $\left(V_{\mathrm{bi}}\right)$ of the $\mathrm{n}^{+} / \mathrm{n}$ junction in thermal equilibrium gradually decreases. This will result in the degradation in field effect passivation, and the recombination of the photo-generated carriers increases. Finally, the density of electrons (n) and holes (p) reduces. $E_{\mathrm{Fn}}$ will move downwards with the decrease of electron density and $E_{\mathrm{Fp}}$ will move upwards with the decrease of hole density gradually. Therefore, the $V_{\mathrm{OC}}$ which equal to quasiFermi splitting of electrons and holes continually reduces with the increase of $\mathrm{CO}_{2} / \mathrm{SiH}_{4}$ flow ratio.

With the increase of $\mathrm{CO}_{2} / \mathrm{SiH}_{4}$ flow ratio, energy conversion efficiency $\left(E_{\mathrm{ta}}\right)$ gradually decreases. It can be easily found that the sharp decrease of $\mathrm{FF}$ is the main factor limiting the conversion efficiency of $\mathrm{SHJ}$ solar cell with $\mathrm{n}$ type $\mathrm{a}-\mathrm{SiO}_{x}: \mathrm{H}$ film. In the next section, further analysis and corresponding optimization will be presented. 


\subsection{Improvement of cell performance by highly phosphorous-doped a-Si:H buffer layer}

Generally, FF is affected by series resistance and parallel resistance. The replacement of $\mathrm{a}-\mathrm{Si}: \mathrm{H}$ with $\mathrm{a}-\mathrm{SiO}_{x}: \mathrm{H}$ layer brings three changes including photo-conductivity $\left(\sigma_{\mathrm{ph}}\right)$ of $\mathrm{n}^{+}$layer, $\mathrm{i} /$ $\mathrm{n}^{+}$interface band structure and $\mathrm{TCO} / \mathrm{n}^{+}$contact characteristic, which may weaken the transport of photo-generated carriers and result in the increase of series resistance. Fig. 8 shows the $\sigma_{\mathrm{ph}}$ of phosphorous-doped a- $\mathrm{SiO}_{x}: \mathrm{H}$ layers as a function of $\mathrm{CO}_{2} /$ $\mathrm{SiH}_{4}$ flow ratio. A gradual decrease in $\sigma_{\text {ph }}$ can be observed. The $\sigma_{\mathrm{ph}}$ is related to the recombination of optically excited carriers, the observed decrease of $\sigma_{\mathrm{ph}}$ is mainly due to the increase of the density of recombination centers. ${ }^{29-31}$ Moreover, the decreased doping efficiency of phosphorous and increasingly intrinsic character with the increase of oxygen content will affect the



Fig. 8 The photoconductivity of phosphorous-doped a-SiO $: \mathrm{H}$ layers as a function of $\mathrm{CO}_{2} / \mathrm{SiH}_{4}$ flow ratio. (a)

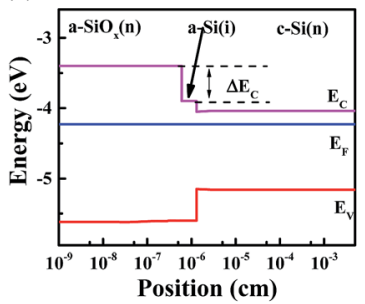

(b)

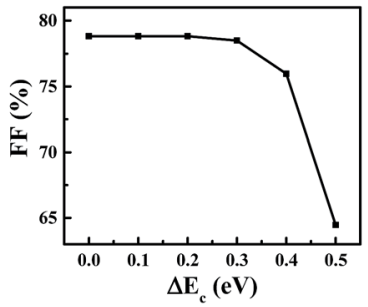

Fig. 9 Energy band diagram at the $\mathrm{i} / \mathrm{n}$ interface (a), simulated FF as a function of conduction band offset (b). $\sigma_{\mathrm{ph}} \cdot{ }^{28,32,33}$ In order to obtain high transmittance, the cost of low $\sigma_{\mathrm{ph}}$ cannot be avoided for $\mathrm{a}-\mathrm{SiO}_{x}: \mathrm{H}$ films. Additionally, the increase in $E_{\text {opt }}$ with increasing $\mathrm{CO}_{2} / \mathrm{SiH}_{4}$ flow ratio results in the enlargement in the band offset at the $\mathrm{i} / \mathrm{n}$ interface. ${ }^{34}$ In this experiment, electrons are collected at the front, an increasing conduction band offset $\left(\Delta E_{\mathrm{c}}\right.$, shown in Fig. 9 (a)) at the interface between intrinsic a-Si:H layer and $\mathrm{n}$-type $\mathrm{a}-\mathrm{SiO}_{x}: \mathrm{H}$ layer may be detrimental, resulting in less efficient transport of carriers. Meantime, the increase of oxygen in n-type $\mathrm{a}^{-\mathrm{SiO}_{x}: \mathrm{H} \text { layer }}$ results in the decrease of carrier density and drop of Fermi level. Therefore, the contact between $\mathrm{n}^{+}$layer and TCO layer is also affected. This may also limit the transport of photo-generated carriers.

In order to investigate the influence of $\Delta E_{\mathrm{c}}$ on the transport characteristic of photo-generated electrons, AFORS-HET was used to simulate the device performance. The contacts between TCO and a-Si:H $\left(\mathrm{p}^{+}\right.$and $\left.\mathrm{n}^{+}\right)$were assumed as flat band to neglect the potential contact influence, and the Fermi level and the valence band bottom of the $\mathrm{a}-\mathrm{SiO}_{x}: \mathrm{H}$ layer were assumed to be fixed to neglect the potential valence band offset influence. Detailed information of the substrate and amorphous silicon layers could be found in Table 1, the simulation result is shown in Fig. 9(b). From Fig. 9(b), the FF does not show a sharp decrease until $\Delta E_{\mathrm{c}}$ is larger than $0.4 \mathrm{eV}$, the value is similar to that other groups have concluded..$^{35,36}$ In this experiment, the band gap of intrinsic a-Si: $\mathrm{H}$ is approximately $1.71 \mathrm{eV}$, and the band gap of n-type a-SiO ${ }_{x}: \mathrm{H}$ layers changes from $1.71 \mathrm{eV}$ to $2.08 \mathrm{eV}$. This means that the $\Delta E_{\mathrm{c}}$ at the $\mathrm{i} / \mathrm{n}^{+}$interface would not exceed $0.185 \mathrm{eV}$ (half of the band gap difference), since $\Delta E_{\mathrm{c}}$ is usually smaller than valance band offset $\left(\Delta E_{\mathrm{v}}\right) \cdot{ }^{37-41}$ That is to say, the $\mathrm{i} / \mathrm{n}^{+}$interface band offset will not lead to the significant decrease of FF. So, the contact between phosphorous-doped a$\mathrm{SiO}_{x}: \mathrm{H}$ layer and TCO layer may be more responsible for the decrease of FF.

In a next step, solar cells with a highly phosphorous-doped aSi:H buffer layer $(2 \mathrm{~nm}$ ) between the TCO layer and n-type a$\mathrm{SiO}_{x}: \mathrm{H}$ layer were prepared. The $\mathrm{PH}_{3} / \mathrm{SiH}_{4}$ flow ratio was $3 \%$ for the a-Si:H buffer layers, while $1.5 \%$ for the n-type a-SiO ${ }_{x}: \mathrm{H}$ layers. Fig. 10 shows the illuminated $I-V$ parameters of solar cells with highly doped a-Si:H buffer layers. The basic trends of $V_{\mathrm{OC}}, J_{\mathrm{SC}}$ and FF do not change, but Fig. 11 clearly shows that the decrease amplitude of FF significantly reduces due to the

Table 1 The set of values for the simulation of the $\mathrm{SHJ}$ solar cells

\begin{tabular}{|c|c|c|c|c|}
\hline Parameters & $\mathrm{a}-S i O_{x}(\mathrm{n})$ & a-SiH (p) & i-layer & $\mathrm{c}-\mathrm{Si}$ \\
\hline Dielectric constant & 11.9 & 11.9 & 11.9 & 11.9 \\
\hline Thickness (nm) & 8 & 15 & 7 & $2 \times 10^{5}$ \\
\hline Band gap (eV) & $1.71-2.21$ & 1.71 & 1.71 & 1.12 \\
\hline Effective conduction band density $\left(\mathrm{cm}^{-3}\right)$ & $1 \times 10^{20}$ & $1 \times 10^{20}$ & $1 \times 10^{20}$ & $2.85 \times 10^{19}$ \\
\hline Effective valence band density $\left(\mathrm{cm}^{-3}\right)$ & $1 \times 10^{20}$ & $1 \times 10^{20}$ & $1 \times 10^{20}$ & $2.69 \times 10^{19}$ \\
\hline Thermal velocity of electrons $\left(\mathrm{cm} \mathrm{s}^{-1}\right)$ & $1 \times 10^{7}$ & $1 \times 10^{7}$ & $1 \times 10^{7}$ & $1 \times 10^{7}$ \\
\hline Thermal velocity of holes $\left(\mathrm{cm} \mathrm{s}^{-1}\right)$ & $1 \times 10^{7}$ & $1 \times 10^{7}$ & $1 \times 10^{7}$ & $1 \times 10^{7}$ \\
\hline Layer density $\left(\mathrm{g} \mathrm{cm}^{-3}\right)$ & 2.328 & 2.328 & 2.328 & 2.328 \\
\hline
\end{tabular}




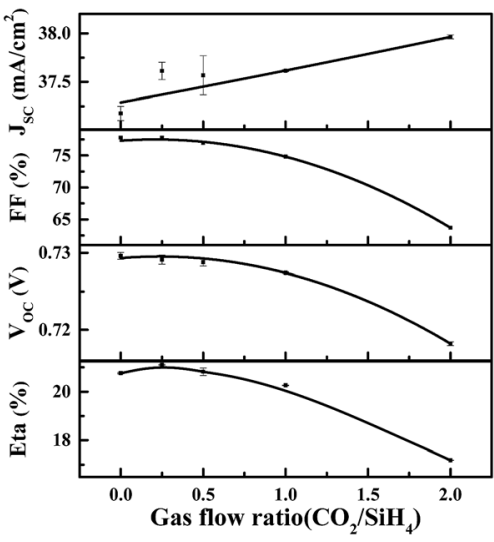

Fig. 10 Illuminated $\mathrm{J}-\mathrm{V}$ results of SHJ solar cells with highly phosphorous doped a-Si:H buffer layer.



Fig. $11 \mathrm{FF}$ as a function of $\mathrm{CO}_{2} / \mathrm{SiH}_{4}$ flow ratio with and without highly phosphorous doped a-Si buffer layer.

introduction of highly phosphorous doped a-Si:H buffer layer. When the $\mathrm{CO}_{2} / \mathrm{SiH}_{4}$ flow ratio increases from 0 to 2, FF shows varying degrees of improvement. Due to the improvement of $\mathrm{FF}$ and $J_{\mathrm{SC}}$, the conversion efficiency increases slightly when $\mathrm{CO}_{2} /$ $\mathrm{SiH}_{4}$ flow ratio is relatively low. Results indicate that the highly phosphorous doped a-Si:H buffer layer improves the TCO/n contact characteristic due to higher carrier density and higher Fermi level. ${ }^{42-51}$

Finally, a total-area conversion efficiency of $21.1 \%$ was achieved on $238.85 \mathrm{~cm}^{2} \mathrm{SHJ}$ solar cell when the $\mathrm{CO}_{2} / \mathrm{SiH}_{4}$ flow ratio is 0.25 . Compared with the standard cell, it exhibits a relative improvement of $2 \%$ in conversion efficiency at room temperature. Generally, the standard cell (a-Si:H $\mathrm{n}^{+}$layer) would show a decrease in $\mathrm{FF}$ when increasing the temperature, whereas the cell with an oxide layer recovers gradually. ${ }^{19,52}$ This means the a$\mathrm{SiO}_{x}: \mathrm{H}$ cell has a low temperature coefficient, which might show a big advantage in the real power generation process.

\section{Conclusions}

In summary, n-type a-SiO ${ }_{x}: \mathrm{H}$ layers were prepared and applied to $\mathrm{SHJ}$ solar cells as window $\mathrm{n}^{+}$layers. The $V_{\mathrm{OC}}$ decreases slightly with the increase of $\mathrm{CO}_{2} / \mathrm{SiH}_{4}$ flow ratio, this may be caused by the dropping of Fermi level which is originated from gradually decreased phosphorous doping efficiency. The application of such layers decreases the $\mathrm{n}^{+}$layers' absorption in short wavelength region, resulting in improvement in $J_{\mathrm{sc}}$. Moreover, through the insertion of a-Si:H buffer layer, the contact between TCO layer and $\mathrm{a}-\mathrm{SiO}_{x}: \mathrm{H}$ layer is greatly improved. The best $\mathrm{SHJ}$ solar cell with a-SiO $x: \mathrm{H}$ layer reached an efficiency of $21.1 \%$ ( $V_{\mathrm{OC}}: 729 \mathrm{mV}, J_{\mathrm{SC}}: 37.6 \mathrm{~mA} \mathrm{~cm}{ }^{-2}$, FF: $77.0 \%$, cell area: 238.95 $\left.\mathrm{cm}^{2}\right)$. The application of wide band-gap a-SiO ${ }_{x}: \mathrm{H}$ layers on $\mathrm{SHJ}$ solar cells shows potential in improving conversion efficiency, the optimal parameters of $\mathrm{a}-\mathrm{SiO}_{x}: \mathrm{H}$ layers need further research for a higher conversion efficiency in the future.

\section{Acknowledgements}

This work was supported by the National Natural Science Foundation of China (51302081, 61575010, 61574009, 11274028, 11574014), Beijing Nova Program (Z141109001814053) and the Science and Technology Commission of Beijing Municipality (Z151100003315018, Z151100003515004). Authors appreciate Mr Mingfang Dai, Dr Yuanmin Li, Dr Hui Zhao, Ms. Lan Chen at Hanergy Thin Film Solar Group, R\&D Center, for great support and helpful discussions. Authors also acknowledge all the colleagues in Thin Film Lab of Beijing University of Technology.

\section{Notes and references}

1 S. De Wolf, A. Descoeudres, Z. C. Holman and C. Ballif, Green, 2012, 2, 7-24.

2 X. Y. Zhang, S. Hargreaves, Y. M. Wan and A. Cuevas, Phys. Status Solidi RRL, 2014, 8, 231-234.

3 M. Taguchi, A. Yano, S. Tohoda, K. Matsuyama, Y. Nakamura, T. Nishiwaki, K. Fujita and E. Maruyama, IEEE Journal of Photovoltaics, 2014, 4, 96-99.

4 A. Descoeudres, L. Barraud, S. De Wolf, B. Strahm, D. Lachenal, C. Guerin, Z. C. Holman, F. Zicarelli, B. Demaurex, J. Seif, J. Holovsky and C. Ballif, Appl. Phys. Lett., 2011, 99, 123506.

5 A. Cuevas and D. Yan, IEEE Journal of Photovoltaics, 2013, 3, 916-923.

6 J. Ramanujam and A. Verma, Mater. Express, 2012, 2, 177196.

7 M. Vanecek, J. Kocka, J. Stuchlik and A. Triska, Solid State Commun., 1981, 39, 1199-1202.

8 E. Fefer, Y. Shapira and I. Balberg, Appl. Phys. Lett., 1995, 67, 371-373.

9 Z. C. Holman, A. Descoeudres, L. Barraud, F. Z. Fernandez, J. P. Seif, S. De Wolf and C. Ballif, IEEE Journal of Photovoltaics, 2012, 2, 7-15.

10 H. Fujiwara and M. Kondo, J. Appl. Phys., 2007, 101, 054516.

11 M. Tanaka, M. Taguchi, T. Matsuyama, T. Sawada, S. Tsuda, S. Nakano, H. Hanafusa and Y. Kuwano, Jpn. J. Appl. Phys., 1992, 31, 3518-3522.

12 M. R. Page, E. Iwaniczko, Y. Q. Xu, L. Roybal, F. Hasoon, Q. Wang and R. S. Crandall, Thin Solid Films, 2011, 519, 4527-4530.

13 H. Watanabe, K. Haga and T. Lohner, J. Non-Cryst. Solids, 1993, 164-166, 1088. 
14 P. Cuony, M. Marending, D. T. L. Alexander, M. Boccard, G. Bugnon, M. Despeisse and C. Ballif, Appl. Phys. Lett., 2010, 97, 143505.

15 V. Smirnov, W. Böttler, A. Lambertz, H. Wang, R. Carius and F. Finger, Phys. Status Solidi C, 2010, 7, 1053-1056.

16 R. Biron, C. Pahud, F. J. Haug, J. Escarre, K. Soderstrom and C. Ballif, J. Appl. Phys., 2011, 110, 124511.

17 J. Park, V. A. Dao, C. Shin, H. Park, M. Kim, J. Jung, D. Kim and J. Yi, Thin Solid Films, 2013, 546, 331-336.

18 P. Sichanugrist, T. Sasaki, A. Asano, Y. Ichikawa and H. Sakai, Sol. Energy Mater. Sol. Cells, 1994, 34, 415-422.

19 J. Peter Seif, A. Descoeudres, M. Filipič, F. Smole, M. Topič, Z. Charles Holman, S. De Wolf and C. Ballif, J. Appl. Phys., 2014, 115, 024502.

20 G. Lucovsky, J. Yang, S. S. Chao, J. E. Tyler and W. Czubatyj, Phys. Rev. B: Condens. Matter Mater. Phys., 1983, 28, 32253233.

21 S. J. Wen, G. Campet, J. Portier, G. Couturier and J. B. Goodenough, Mater. Sci. Eng., B, 1992, 14, 115-119.

22 M. Niwano, J. Kageyama, K. Kinashi, N. Miyamoto and K. Honma, J. Vac. Sci. Technol., A, 1994, 12, 465-470.

23 D. Das, S. M. Iftiquar and A. K. Barua, J. Non-Cryst. Solids, 1997, 210, 148-154.

24 J. E. Lee, J. H. Park, J. Yoo, K. H. Yoon, D. Kim and J. S. Cho, Solid State Sci., 2013, 20, 70-74.

25 M. Koos, I. Pocsik and I. K. Somogyi, J. Non-Cryst. Solids, 1987, 90, 469-471.

26 S. De Wolf and M. Kondo, J. Appl. Phys., 2009, 105, 103707.

27 K. Hubner, Phys. Status Solidi A, 1980, 61, 665-673.

28 A. Janotta, R. Janssen, M. Schmidt, T. Graf, M. Stutzmann, L. Görgens, A. Bergmaier, G. Dollinger, C. Hammerl, S. Schreiber and B. Stritzker, Phys. Rev. B: Condens. Matter Mater. Phys., 2004, 69, 115206.

29 T. Itoh, R. Katayama, K. Yamakawa, K. Matsui, M. Saito, S. Sugiyama, P. Sichanugrist, S. Nonomura and M. Konagai, Jpn. J. Appl. Phys., 2015, 54, 08KB11.

30 M. C. Rossi, M. S. Brandt and M. Stutzmann, Appl. Surf. Sci., 1996, 102, 323-326.

31 J.-J. Park, Y.-K. Kim, S.-W. Lee, Y.-J. Lee, J.-S. Yi, S. Q. Hussain and N. Balaji, Transactions on Electrical and Electronic Materials, 2012, 13, 192-195.

32 W. Y. Ching, Phys. Rev. B: Condens. Matter Mater. Phys., 1980, 22, 2816-2822.

33 D. Das and A. K. Barua, Sol. Energy Mater. Sol. Cells, 2000, 60, 167-179.
34 T. F. Schulze, L. Korte, F. Ruske and B. Rech, Phys. Rev. B: Condens. Matter Mater. Phys., 2011, 83, 165314.

35 M. Liebhaber, M. Mews, T. F. Schulze, L. Korte, B. Rech and K. Lips, Appl. Phys. Lett., 2015, 106, 031601.

36 M. Rahmouni, A. Datta, P. Chatterjee, J. Damon-Lacoste, C. Ballif and P. R. I. Cabarrocas, J. Appl. Phys., 2010, 107, 054521.

37 H. Mimura and Y. Hatanaka, Appl. Phys. Lett., 1987, 50, 326328.

38 H. Eschrich, J. Bruns, L. Elstner and C. Swiatkowski, J. NonCryst. Solids, 1993, 166, 717-720.

39 J. M. Essick and J. D. Cohen, Appl. Phys. Lett., 1989, 55, 12321234.

40 W. Fuhs, L. Korte and M. Schmidt, J. Optoelectron. Adv. Mater., 2006, 8, 1989-1995.

41 M. Schmidt, L. Korte, A. Laades, R. Stangl and C. H. Schubert, Thin Solid Films, 2007, 515, 7475-7480.

42 R. Timmreck, S. Olthof, K. Leo and M. K. Riede, J. Appl. Phys., 2010, 108, 033108.

43 A. N. Corpus-Mendoza, M. M. De Souza and F. U. Hamelmann, IEEE Journal of Photovoltaics, 2015, 5, 22-27.

44 P. D. Veneri, L. V. Mercaldo and I. Usatii, Appl. Phys. Lett., 2010, 97, 023512.

45 J. Sritharathikhun, H. Yamamoto, S. Miyajima, A. Yamada and M. Konagai, Jpn. J. Appl. Phys., 2008, 47, 8452-8455.

46 A. Kanevce and W. K. Metzger, J. Appl. Phys., 2009, 105, 094507.

47 M. Tucci, L. Serenelli, S. De Iuliis, M. Izzi, G. de Cesare and D. Caputo, in Physics and Technology of AmorphousCrystalline Heterostructure Silicon Solar Cells, ed. W. G. J. H. M. van Sark, L. Korte and F. Roca, Springer Berlin Heidelberg, Berlin, Heidelberg, 2012, pp. 331-375, DOI: 10.1007/978-3-642-22275-7_10.

48 L. V. Mercaldo, I. Usatii and P. D. Veneri, Energies, 2016, 9, 218.

49 J. J. Liou, IEE Proceedings, Part G: Circuits, Devices and Systems, 1992, 139, 646-654.

50 A. Blicher, Rep. Prog. Phys., 1982, 45, 427-468.

51 J. Wang, H. B. Wang, J. Zhang, X. J. Yan and D. H. Yan, J. Appl. Phys., 2005, 97, 026106.

52 M. W. M. van Cleef, F. A. Rubinelli, R. Rizzoli, R. Pinghini, R. E. I. Schropp and W. F. van der Weg, Jpn. J. Appl. Phys., 1998, 37, 3926-3932. 